\title{
Development of Pattern Block Shaping in Accordance with the Real Sleeve-in Shapes
}

\author{
Nadejzda KOCHANOVA*a, Victor KUZMICHEV ${ }^{* a}$, Dominique C. ADOLPHE ${ }^{b}$ \\ avanovo State Textile Academy, Ivanovo, Russia; \\ ${ }^{\mathrm{b}}$ University of Haute Alsace - ENSISA, Mulhouse, France
}

\begin{abstract}
Mathematical tool for the exact pattern block shaping during the investigation of the scanned system "arm-sleeve» in accordance with the established indexes of outline shape are developed. The equations allowing predict the air gaps and sleeve width which made from different materials in system «arm-sleeve» are established.
\end{abstract}

Keywords: sleeve-in, shaping, bodyscanner, parameterization, pattern making

\section{Introduction}

Nowadays the sleeve basic block shaping to get the desirable clothes shape is the process which based on the intuitive approach mainly. To shape the basic sleeve, to change the sizes and contour lines configuration of initial block or its part by means of parallel or conical extension. Sleeve shapes obtained are describing by verbal terms (such as bishop, leg of mutton sleeve, buffed sleeve) which enough for the visual presentation of new design but couldn't use in 3D virtual realty because of absent quantities values. So for CAD development it's important to create the new way of possible sleeve shapes describing which can apply to their block patterns for its shaping.

The main goal of this research is to establish the relations between the conditions of basic sleeve-in flat block shaping, on the one hand, and the indexes of real 3D sleeve shapes made from the shaping block after its sewing in armhole, on the second hand. The object of research is the one seam sleeve-in with a conical extension on the bottom and the cup.

\section{Objects, methodics and analytical methods used}

Research included the next steps:

- basic sleeve block (BSB) shaping into modelled sleeve block (MSB),

- parameterization of MSB by means of original indexes (1st data base),

- scanning technology,

- digitalization of the system «arm-sleeve»,

- parameterization of the 3D sleeve shape and the air gaps on the different anthropometric levels (2nd data base),

- finding the relations between the both data bases indexes.

In our experiment BSB was designed for typical female body 170-92-100 with the next eases (the ease is the difference between the body size and the similar line located on the block pattern): to arm girth $3,5 \mathrm{~cm}$ (sleeve cup width was $16,1 \mathrm{~cm}$ ), to sleeve cup height $-1,8 \mathrm{~cm}$ (sleeve cup height was $16,2 \mathrm{~cm}$ ), to wrist girth $-8 \mathrm{~cm}$, to arm length $-(-) 1,7 \mathrm{~cm}$.

BSB was transformed into MSB by two ways. First way is to increase the bottom length. Therefore BSB was cut along 3 lines from bottom line to the next levels - under elbow girth, elbow girth, biceps girth, armhole depth, cup height. Along these lines the bottom length were increased by conical transforming in basic values $0.5,0.75,1.0 \mathrm{~cm}$ and then for each level mentioned the basic values of transforming were increased in proportion - the higher the bigger.

Second way is to increase the sleeve cup width. We used the same approach as before but the BSB was cut from the cup line to the same levels. The values of conical transforming were calculated in the same way. So we have two groups of sleeves - (1) with increased bottom line and stable cup line, (2) with increased cup line and stable bottom line.

After BSB transforming each new MSB had the square bigger than BSB. By these ways we get 30 MSB based on the only one BSB: 15 MSB with the bottom line increased, 15 MSB with the cup line increased.

\footnotetext{
* kshi@igta.ru; +7-4932-328545; www.igta.ru
} 
For MSB parameterization we fix together BSB and MSB and measure the distance between both contour lines along the axes drawing from common center. Scheme of MSB parameterization shown on figure 1. Intervals of parameter transforming of MSB - in table 1.
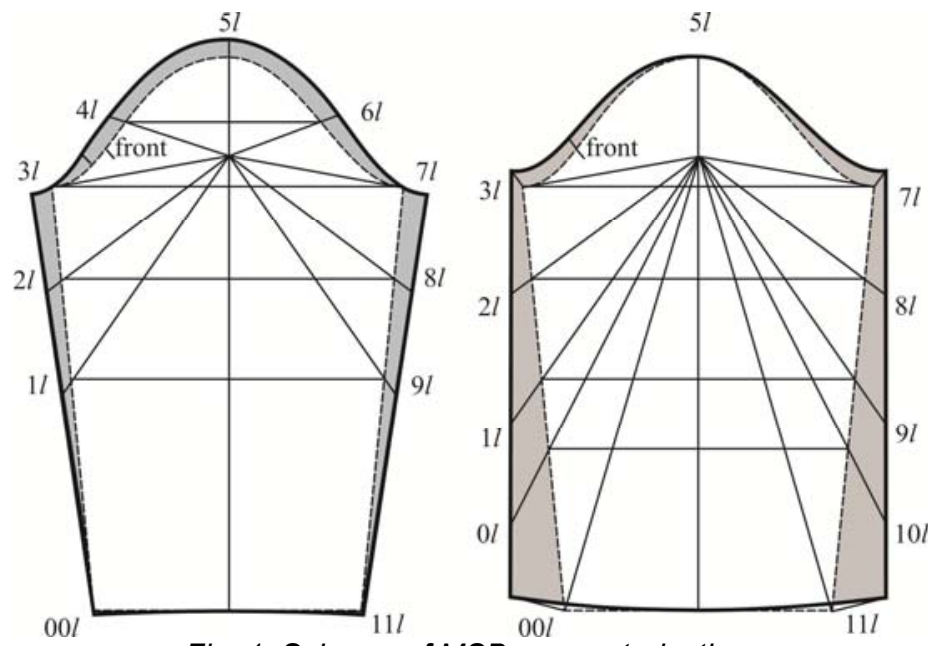

Fig. 1. Scheme of MSB parameterization.

Table 1. Intervals of parameter transforming of MSB.

\begin{tabular}{|c|c|c|c|}
\hline \multirow[t]{3}{*}{ № } & \multicolumn{3}{|c|}{ sleeve-in with a conical extension } \\
\hline & \multicolumn{2}{|c|}{ on the cup, $\mathrm{cm}$} & \multirow{2}{*}{$\begin{array}{c}\text { on the bottom, } \mathrm{cm} \\
\text { data span }\end{array}$} \\
\hline & index & data span & \\
\hline 1 & $00 /$ & 0 & $4 \ldots 26$ \\
\hline 2 & $0 I$ & - & $0 \ldots 16,2$ \\
\hline 3 & $1 /$ & $0 \ldots 6,8$ & $0 \ldots 25,3$ \\
\hline 4 & $2 I$ & $0 \ldots 7,4$ & $0 \ldots 13,8$ \\
\hline 5 & $3 /$ & $0 \ldots 8$ & $0 \ldots 7,7$ \\
\hline 6 & $4 I$ & $0 \ldots 8,5$ & - \\
\hline 7 & $5 /$ & $0,7 \ldots 2,1$ & 0 \\
\hline 8 & $6 /$ & $0 \ldots 7,7$ & - \\
\hline 9 & 71 & $0 \ldots 8,5$ & $0 \ldots 1,3$ \\
\hline 10 & 81 & $0 \ldots 7$ & $0 \ldots 2,8$ \\
\hline 11 & 9/ & $0 \ldots 6,2$ & $0 \ldots 5,3$ \\
\hline 12 & $10 /$ & - & $0 \ldots 11,3$ \\
\hline 13 & $11 /$ & 0 & $3,7 \ldots 13,2$ \\
\hline
\end{tabular}

Two kinds of textile materials used for sleeve cutting - relatively soft and relatively hard. Armhole sizes which formed from the front and the back were stable: length is $45,8 \mathrm{~cm}$, width is $12,8 \mathrm{~cm}$. For setting the sleeve cup into the armhole we put the additional cup length into pleats with $1 \ldots 1.5 \mathrm{~cm}$ depth.

All systems arm-sleeve were shared and then we connected the arm image and the sleeve image by Adobe PhotoShop to get the front and profile views. All projections were parameterized in accordance with the scheme shown on figure 2. Intervals of parameter transforming of front and profile views in the system «arm - sleeve» are shown in table 2. 


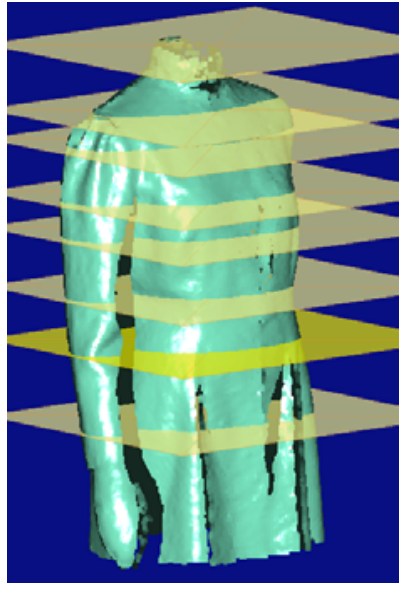

a

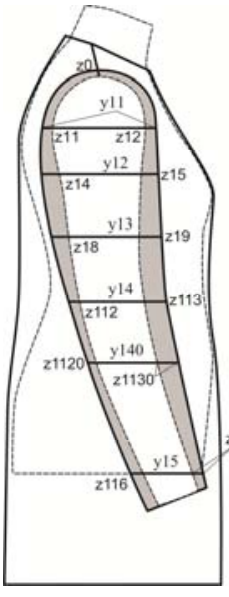

$b$

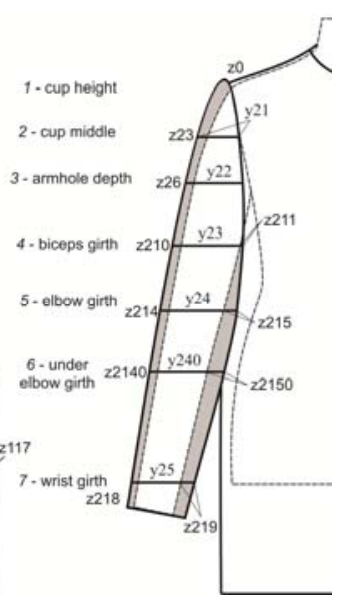

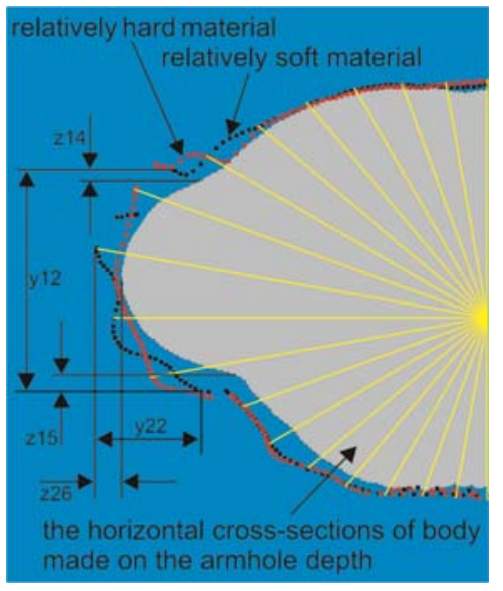

c

Fig. 2. Scheme of system «arm-sleeve» parameterization: a - the scanavatar with the cross-sections, $b$ - the sleeve width $\left(\mathrm{y}_{\mathrm{i}}\right)$ and air gaps $\left(\mathrm{z}_{\mathrm{i}}\right), c$ - the horizontal cross-sections made on the armhole depth.

Table 2. Intervals of parameter transforming of front and profile views in the system «arm - sleeve».

\begin{tabular}{|c|c|c|c|c|c|c|c|c|c|c|c|}
\hline \multicolumn{6}{|c|}{$\begin{array}{l}\text { Air gaps between the arm and the sleeve in the system } \\
\text { «arm - sleeve» measured near different contour lines } \\
\text { along the levels, cm }\end{array}$} & \multicolumn{6}{|c|}{ Sleeve width on the different views, $\mathrm{cm}$} \\
\hline \multicolumn{3}{|c|}{$\begin{array}{l}\text { sleeve-in with a conical } \\
\text { extension on the cup }\end{array}$} & \multicolumn{3}{|c|}{$\begin{array}{l}\text { sleeve-in with a conical } \\
\text { extension on the bottom }\end{array}$} & \multicolumn{3}{|c|}{$\begin{array}{l}\text { sleeve-in with a conical } \\
\text { extension on the cup }\end{array}$} & \multicolumn{3}{|c|}{$\begin{array}{l}\text { sleeve-in with a conical } \\
\text { extension on the bottom }\end{array}$} \\
\hline № & index & data span & № & index & data span & № & index & data span & № & index & data span \\
\hline 1 & $\mathrm{z0}$ & $0,2 \ldots 7,4$ & - & - & - & - & - & - & - & - & - \\
\hline 2 & $\mathrm{z} 11$ & $0,2 \ldots 2,5$ & - & - & - & \multirow{2}{*}{41} & \multirow{2}{*}{ y11 } & \multirow{2}{*}{$12,9 \ldots 16$} & \multirow[b]{2}{*}{-} & \multirow[b]{2}{*}{-} & \multirow{2}{*}{-} \\
\hline 3 & $\mathrm{z12}$ & $0 \ldots 2,4$ & - & - & - & & & & & & \\
\hline 4 & z23 & $0 \ldots 4,1$ & - & - & - & 42 & $y 21$ & $3,4 \ldots 7,2$ & - & - & - \\
\hline 5 & $z 14$ & $0 \ldots 3,6$ & 21 & $z 14$ & $0 \ldots 2,1$ & \multirow[b]{2}{*}{43} & \multirow{2}{*}{ y12 } & \multirow{2}{*}{$11,1 \ldots 16,1$} & \multirow{2}{*}{51} & \multirow{2}{*}{ y12 } & \multirow{2}{*}{$10,4 \ldots 14$} \\
\hline 6 & $z 15$ & $0,4 \ldots 4,3$ & 22 & $z 15$ & $0,5 \ldots 3,5$ & & & & & & \\
\hline 7 & Z26 & $0,1 \ldots 2,6$ & 23 & z26 & $0 \ldots 1,6$ & \multirow{2}{*}{44} & \multirow{2}{*}{ y22 } & \multirow{2}{*}{$6,6 \ldots 11,4$} & \multirow{2}{*}{52} & \multirow{2}{*}{ y22 } & \multirow{2}{*}{$5,8 \ldots 9,7$} \\
\hline 8 & $z 27$ & - & 24 & $z 27$ & - & & & & & & \\
\hline 9 & z18 & $0 \ldots 3,1$ & 25 & z18 & $0 \ldots 2,4$ & \multirow{2}{*}{45} & \multirow{2}{*}{ y13 } & \multirow{2}{*}{$10,2 \ldots 15,2$} & \multirow{2}{*}{53} & \multirow{2}{*}{ y13 } & \multirow{2}{*}{$10,1 \ldots 14,3$} \\
\hline 10 & z19 & $1,3 \ldots 4,7$ & 26 & $z 19$ & $1,2 \ldots 5,1$ & & & & & & \\
\hline 11 & $z 210$ & $0,3 \ldots 2,3$ & 27 & $z 210$ & $0 \ldots 3,6$ & & & & & & \\
\hline 12 & $z 211$ & $0 \ldots 1$ & 28 & $z 211$ & $0 \ldots 1,2$ & 46 & y23 & $8,3 \ldots 11,5$ & 54 & y23 & $7,5 \ldots 12,2$ \\
\hline 13 & z112 & $0 \ldots 1,8$ & 29 & z112 & $0 \ldots 2,2$ & & & & & & \\
\hline 14 & $z 113$ & $1,3 \ldots 4,7$ & 30 & $z 113$ & $1,1 \ldots 5,6$ & $4 I$ & y14 & $9,3 \ldots 13,8$ & 55 & y14 & $9,6 \ldots 14,3$ \\
\hline 15 & z214 & $0,2 \ldots 2,1$ & 31 & z214 & $0 \ldots 5$ & & & & & & \\
\hline 16 & z215 & $0 \ldots 2$ & 32 & z215 & $0 \ldots 2,3$ & 48 & y24 & $7,7 \ldots 11,7$ & 56 & y24 & $8,1 \ldots 13,2$ \\
\hline- & - & - & 33 & $\mathrm{z} 1120$ & $0,8 \ldots 3,4$ & & & & & & \\
\hline- & - & - & 34 & $\mathrm{z} 1130$ & $0,5 \ldots 5,4$ & - & - & - & 57 & y140 & $9,3 \ldots 14,4$ \\
\hline- & - & - & 35 & z2140 & $0 \ldots 6,6$ & & & & & & \\
\hline- & - & - & 36 & z2150 & $0,2 \ldots 3,6$ & - & - & - & 58 & y240 & $7,5 \ldots 14,2$ \\
\hline 17 & $z 116$ & $1,3 \ldots 3,7$ & 37 & $\mathrm{z} 116$ & $3,9 \ldots 7,6$ & & & & & & \\
\hline 18 & $\mathrm{z} 117$ & $0 \ldots 0,9$ & 38 & z117 & $0 \ldots 4,4$ & 49 & y15 & $6,4 \ldots 9,5$ & 59 & y15 & $9,4 \ldots 14,6$ \\
\hline 19 & z218 & $0,3 \ldots 1,8$ & 39 & z218 & $0,8 \ldots 10,9$ & 50 & & & 60 & & \\
\hline 20 & z219 & $0 \ldots 2,9$ & 40 & z219 & $0,4 \ldots 5,8$ & 50 & $y<5$ & $6,4 \ldots 9,1$ & 60 & $y 25$ & $7,9 \ldots 1 /, 4$ \\
\hline
\end{tabular}

So, 2 data bases were obtained: 1st data base related to all possible MSB, 2nd data base related to all possible sleeve-in outline shapes obtained by using MSB. Existing relations between some indices from both data bases were established by correlative and regressive analysis under the confidence figure $95 \%$.

The analysis of the correlative relations shows that shaping of sleeves made of different fabrics proceeds in different ways. The contour lines of the arm and sleeves made of different materials having different values of air gaps are shown on figure 3 . Figure 3 shows very strong influence of the kind of the material on its ability of shaping near the armhole seam. As for relatively soft fabric art. 286(2), figure 3, a shows that all unnecessary, additional sleeve volume in the upper part is located mainly at the front side. As for relatively soft fabric art 1589ugi, figure 3, c shows that unnecessary additional volume is removed to the back contour lines. 


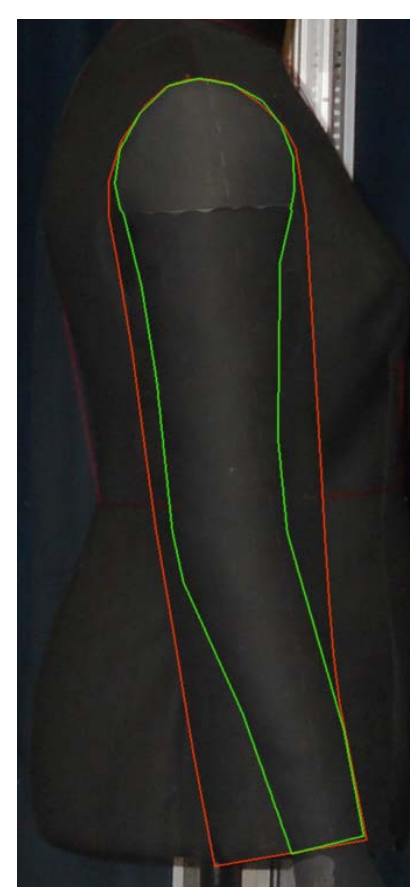

a

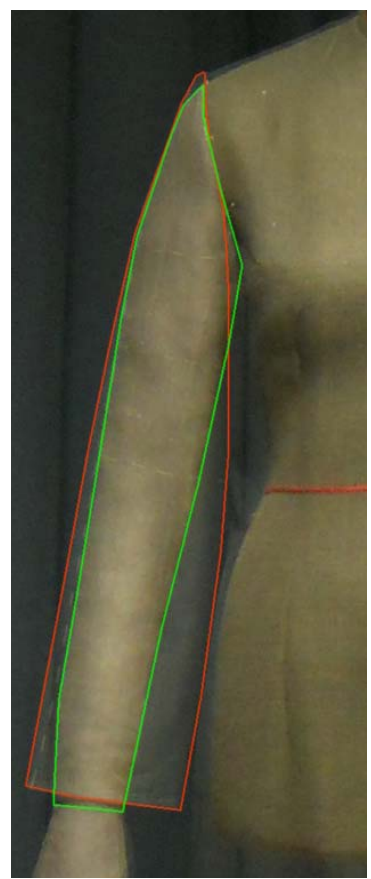

b

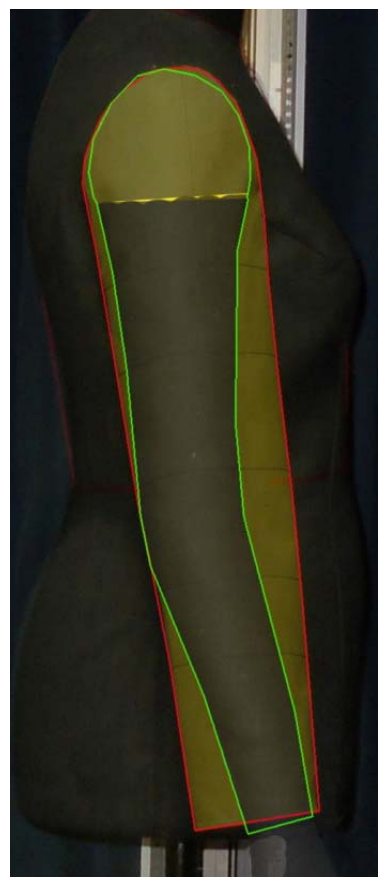

C

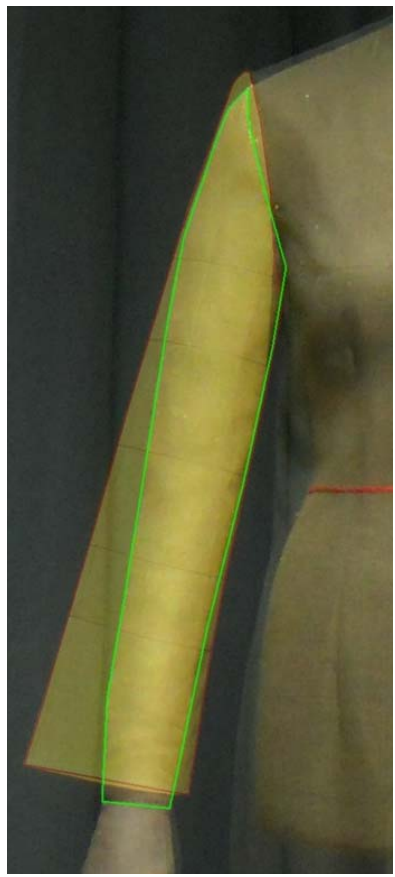

$d$

Fig. 3. Outlines of elements of the system «arm-sleeve» with using of different textile materials: a, b-relatively soft art. 286(2), c, d-relatively hard art. 1589ugi.

The down seam and the turn of the armhole to the front influence greatly on the sleeve shaping for relatively soft material sleeves. It is confirmed by large values of air gaps along the front and down contour lines in comparison with the same ones for relatively hard material sleeves.

The pleats put along the cup affect shaping of relatively hard material sleeves: more pleats - larger values of the back and the upper contour lines.

Therefore, it is necessary to parameterize in some kinds of materials separately or using the complex index of characteristics responsible for shaping peculiarities in future.

This work researches the influence of the concrete textile materials. The equations for calculations of air gap values on the levels of cup middle, cup depth, biceps girth, elbow girth are shown below:

Table 3. Equations for calculation of air gap values of the system «arm-sleeve» (fragment).

\begin{tabular}{|c|c|c|c|c|c|}
\hline \multirow{2}{*}{$\begin{array}{l}\text { The kinds } \\
\text { of textile } \\
\text { materials }\end{array}$} & \multicolumn{5}{|c|}{ Equations for calculation of air gap values of the system «arm-sleeve» (values of correlative) } \\
\hline & cup middle & armhole depth & biceps girth & elbow girth & wrist girth \\
\hline \multicolumn{6}{|c|}{ sleeve-in with a conical extension on the cup } \\
\hline art. 286(2) & $\begin{array}{c}z 23=0,27 \cdot 4 / \text { (or } \\
6 /)-0,01, \\
(r=0,94)\end{array}$ & $\begin{array}{c}z 15=0,43 \cdot 3 / \text { (or } \\
7 l)+0,82, \\
(r=0,9)\end{array}$ & $\begin{array}{c}z 19=0,4 \cdot 2 l \text { (or } \\
8 /)+1,58 \\
(r=0,9)\end{array}$ & $\begin{array}{c}z 113=0,4 \cdot 1 / \text { (or } \\
9 /)+1,61 \\
(r=0,87)\end{array}$ & - \\
\hline art. 1589ugi & $\begin{array}{c}\mathrm{z} 23=0,5 \cdot 4 I \text { (or } \\
6 /)-0,16 \\
(r=0,96)\end{array}$ & $\begin{array}{c}\mathrm{z} 26=0,3 \cdot 3 / \text { (or } \\
7 I)+0,13 \\
(\mathrm{r}=1)\end{array}$ & $\begin{array}{c}z 210=0,25 \cdot 2 l \\
(\text { or } 8 l)+0,31 \\
(r=0,98)\end{array}$ & $\begin{array}{c}z 214=0,25 \cdot 1 / \\
(\text { or } 9 /)+0,35 \\
(r=0,98)\end{array}$ & - \\
\hline \multicolumn{6}{|c|}{ sleeve-in with a conical extension on the bottom } \\
\hline art. 286(2) & - & $\begin{array}{c}z 15=0,28 \cdot 3 I \text { (or } \\
7 I)+0,96, \\
(r=0,9)\end{array}$ & $\begin{array}{c}z 19=0,19 \cdot 2 l \text { (or } \\
8 /)+1,41, \\
(r=0,9)\end{array}$ & $\begin{array}{c}z 113=0,12 \cdot 1 / \\
(\text { or } 9 /)+1,33 \\
(r=0,92)\end{array}$ & $\begin{array}{c}z 219=0,42 \cdot 11 / \\
(\text { or } 00 /)-0,39, \\
(r=0,83)\end{array}$ \\
\hline art. 1589ugi & - & $\begin{array}{c}z 26=0,13 \cdot 3 l \text { (or } \\
7 l)+0,57, \\
(r=1)\end{array}$ & $\begin{array}{c}z 210=0,19 \cdot 2 l \\
\quad(\text { or } 8 /)+0,91 \\
(r=0,97)\end{array}$ & $\begin{array}{c}z 214=0,16 \cdot 1 / \\
(\text { or } 9 /)+1,23 \\
(r=0,94)\end{array}$ & $\begin{array}{c}z 218=0,42 \cdot 00 / \\
(\text { or } 11 /)+0,09, \\
(r=0,94)\end{array}$ \\
\hline
\end{tabular}

Note: the schemes of parameter measuring of the pattern block $00 / . . .11$ l are shown on figure 1 , digitalized system «arm-sleeve» - on figure 2 .

The verification of the equations with the help of the mathematical statistics shows that they are adequate to the real process of shaping under the confidence figure $95 \%$. The differences of calculated and virtual values of air gaps of the system «arm-sleeve» don't exceed $10 \%$.

Thus, this mathematical apparatus allows to design sleeve shaping specially with help of indices of the modelled sleeve block. 


\section{Results}

1. Scheme of sleeve block parameterization.

2. Mathematical equations for describing the pattern block shaping instead of present intuitive approach are developed. They modeled the system «arm - sleeve» in accordance with the established indexes of outline shape done from different textile fabrics. The equations allowing account the air gaps in system «arm - sleeve» on the different levels (cup middle, cup depth, biceps girth, elbow girth) are established.

3. Complex classification of women set-in sleeves including the quantitative and qualitative parameters which joining its shapes and pattern block was created by first time. Qualitative and quantitative indexes for describing the more typical sleeve shapes are included: 1 - traditional verbal records taken from costume history, 2 - indiexes measured on the front and profile views of system «arm - sleeve», 3 - air gaps measured in vertical and horizontal cross-sections, 4 - values of transforming BSB into MSB. The structure of new classification shown below in the table 4.

Table 4. Complex classification for integrated sleeve design in $2 D$ and $3 D$ (fragment).

\begin{tabular}{|c|c|c|c|c|c|c|c|}
\hline \multirow{2}{*}{$\begin{array}{l}\text { Sleeve } \\
\text { level of } \\
\text { paramete-r } \\
\text { ization }\end{array}$} & \multicolumn{2}{|c|}{$\begin{array}{l}\text { Sleeve width on the } \\
\text { different views, } \mathrm{cm}\end{array}$} & \multicolumn{4}{|c|}{$\begin{array}{l}\text { Air gaps between the arm and the sleeve in } \\
\text { system «arm - sleeve» measured near different } \\
\text { contour lines along the levels, cm }\end{array}$} & \multirow{2}{*}{$\begin{array}{l}\text { Values of } \\
\text { transforming BSB into } \\
\text { MSB, measured } \\
\text { along the axes } \\
\text { drawing from } \\
\text { common center, cm }\end{array}$} \\
\hline & front & profile & back & front & upper & down & \\
\hline \multicolumn{8}{|c|}{ Sleeve with the moderate cup volume named buffed sleeve } \\
\hline $\begin{array}{l}\text { cup middle } \\
\text { (2) }\end{array}$ & $8,7 \pm 1,1$ & $\begin{array}{c}13,6 \pm \\
0,9\end{array}$ & $\begin{array}{c}1,95 \pm \\
0,35\end{array}$ & $1,8 \pm 0,3$ & $\begin{array}{c}2,45 \pm \\
0,45\end{array}$ & - & $4,8 \pm 1$ \\
\hline $\begin{array}{l}\text { armhole } \\
\text { depth (3) }\end{array}$ & $10,8 \pm 1,1$ & $\begin{array}{c}12,1 \pm \\
0,9 \\
\end{array}$ & $\begin{array}{c}1,95 \pm \\
0,35\end{array}$ & $3,6 \pm 0,4$ & $\begin{array}{l}1,45 \pm \\
0,25\end{array}$ & - & $3,45 \pm 0,85$ \\
\hline $\begin{array}{l}\text { biceps } \\
\text { girth (4) }\end{array}$ & $12,5 \pm 1,1$ & $12,8 \pm 1$ & $\begin{array}{c}1,45 \pm \\
0,25\end{array}$ & $3,4 \pm 0,5$ & $\begin{array}{c}1,45 \pm \\
0,25\end{array}$ & $\begin{array}{c}0,7 \pm \\
0,1 \\
\end{array}$ & 0 \\
\hline $\begin{array}{l}\text { elbow girth } \\
\text { (5) }\end{array}$ & $11,9 \pm 0,9$ & $\begin{array}{c}12,2 \pm \\
0,9 \\
\end{array}$ & $\begin{array}{l}1,05 \pm \\
0,15 \\
\end{array}$ & $3,1 \pm 0,5$ & $\begin{array}{l}1,45 \pm \\
0,25 \\
\end{array}$ & $3 \pm 0,5$ & 0 \\
\hline $\begin{array}{l}\text { wrist girth } \\
\text { (7) }\end{array}$ & $7,5 \pm 0,3$ & $8,2 \pm 0,3$ & $2,8 \pm 0,5$ & $\begin{array}{c}1,45 \pm \\
0,25 \\
\end{array}$ & $1,3 \pm 0,2$ & $\begin{array}{c}2,5 \pm \\
0,4\end{array}$ & 0 \\
\hline \multicolumn{8}{|c|}{ Sleeve with the moderate cup volume named «leg of mutton» sleeve } \\
\hline $\begin{array}{l}\text { cup middle } \\
(2)\end{array}$ & $11 \pm 1,1$ & $\begin{array}{c}15,5 \pm \\
0,9 \\
\end{array}$ & $\begin{array}{c}2,75 \pm \\
0,35 \\
\end{array}$ & $2,5 \pm 0,3$ & $\begin{array}{c}3,45 \pm \\
0,25 \\
\end{array}$ & - & $6 \pm 1,3$ \\
\hline $\begin{array}{l}\text { armhole } \\
\text { depth (3) }\end{array}$ & $13,1 \pm 1,1$ & $14 \pm 0,9$ & $\begin{array}{c}2,75 \pm \\
0,35\end{array}$ & $4,5 \pm 0,4$ & $\begin{array}{c}2,05 \pm \\
0,25\end{array}$ & - & $5,45 \pm 1,45$ \\
\hline $\begin{array}{l}\text { biceps } \\
\text { girth (4) }\end{array}$ & $14,8 \pm 1,1$ & $14,9 \pm 1$ & $\begin{array}{c}2,05 \pm \\
0,25\end{array}$ & $4,5 \pm 0,5$ & $\begin{array}{c}2,05 \pm \\
0,25\end{array}$ & $1 \pm 0,1$ & $4,45 \pm 1,65$ \\
\hline $\begin{array}{l}\text { elbow girth } \\
\text { (5) }\end{array}$ & $13,8 \pm 0,9$ & $\begin{array}{c}14,1 \pm \\
0,9\end{array}$ & $\begin{array}{c}1,45 \pm \\
0,15\end{array}$ & $4,2 \pm 0,5$ & $\begin{array}{c}2,05 \pm \\
0,25\end{array}$ & $\begin{array}{c}4,1 \pm \\
0,5\end{array}$ & 0 \\
\hline $\begin{array}{l}\text { wrist girth } \\
\text { (7) }\end{array}$ & $8,2 \pm 0,3$ & $8,9 \pm 0,3$ & $3,7 \pm 0,5$ & $\begin{array}{c}2,05 \pm \\
0,25 \\
\end{array}$ & $1,8 \pm 0,2$ & $\begin{array}{c}3,4 \pm \\
0,4\end{array}$ & 0 \\
\hline \multicolumn{8}{|c|}{ Sleeve with the moderate cup volume } \\
\hline $\begin{array}{l}\text { cup middle } \\
(2)\end{array}$ & $13,3 \pm 1,1$ & $\begin{array}{c}17,4 \pm \\
0,9 \\
\end{array}$ & $\begin{array}{c}3,55 \pm \\
0,35 \\
\end{array}$ & $3,2 \pm 0,3$ & $\begin{array}{c}4,45 \pm \\
0,25\end{array}$ & - & $7,5 \pm 1$ \\
\hline $\begin{array}{l}\text { armhole } \\
\text { depth (3) }\end{array}$ & $15,4 \pm 1,1$ & $\begin{array}{c}15,9 \pm \\
0,9\end{array}$ & $\begin{array}{c}3,55 \pm \\
0,35\end{array}$ & $5,4 \pm 0,4$ & $\begin{array}{c}2,65 \pm \\
0,25\end{array}$ & - & $7,65 \pm 0,85$ \\
\hline $\begin{array}{l}\text { biceps } \\
\text { girth (4) }\end{array}$ & $17,1 \pm 1,1$ & $17 \pm 1$ & $\begin{array}{c}2,65 \pm \\
0,25\end{array}$ & $5,6 \pm 0,5$ & $\begin{array}{c}2,65 \pm \\
0,25\end{array}$ & $\begin{array}{c}1,3 \pm \\
0,1\end{array}$ & $6,55 \pm 0,85$ \\
\hline $\begin{array}{l}\text { elbow girth } \\
\text { (5) }\end{array}$ & $15,7 \pm 0,9$ & $16 \pm 0,9$ & $\begin{array}{l}1,85 \pm \\
0,15\end{array}$ & $5,3 \pm 0,5$ & $\begin{array}{c}2,65 \pm \\
0,25\end{array}$ & $\begin{array}{c}5,2 \pm \\
0,5\end{array}$ & $5,9 \pm 0,9$ \\
\hline $\begin{array}{l}\text { wrist girth } \\
\text { (7) }\end{array}$ & $8,9 \pm 0,3$ & $9,6 \pm 0,3$ & $4,6 \pm 0,5$ & $\begin{array}{c}2,65 \pm \\
0,25 \\
\end{array}$ & $2,3 \pm 0,2$ & $\begin{array}{c}4,3 \pm \\
0,4 \\
\end{array}$ & 0 \\
\hline
\end{tabular}

\section{Conclusion}

New results let us to connect the indexes measuring on the different steps of sleeve design and allow transform 2D block patterns into 3D sleeve shapes in accordance with the established relations. 